\title{
Using the VIKOR method to evaluate the design of a water quality monitoring network in a watershed
}

\author{
C.-L. Chang $\cdot$ Y.-T. Lin
}

Received: 30 July 2012/Revised: 30 December 2012/ Accepted: 2 January 2013/Published online: 15 February 2013

(C) Islamic Azad University (IAU) 2013

\begin{abstract}
Water quality monitoring stations play critical roles for analyzing the information of water quality conditions in a watershed. The understanding of water quality conditions of a river system is very important for water resource management. This study applied the VIKOR method, a commonly used method in multiple criteria analysis, to evaluate the design of the water quality monitoring network in the Taipei Water Resource Domain (TWRD). Five criteria were selected for multiple criteria analysis: non-point source pollution, green cover ratio, landslide area ratio, over-utilization area ratio of hillsides, and density of water quality monitoring stations. This study recommended several areas where there is a need for sufficient monitoring records of water quality. The result shows that more monitoring stations are needed in the BeiShih Creek Basin. Although the Nan-Shih Creek Basin covers larger area than the Bei-Shih Creek Basin and the Sin-Dian Creek Basin, it can accept less density of water quality monitoring stations.
\end{abstract}

Keywords Monitoring network $\cdot$ Multiple criteria analysis · VIKOR $\cdot$ Water quality

\section{Introduction}

Taiwan's annual precipitation is about $2,500 \mathrm{~mm}$, which is almost three times the world's average. However, useful water resources are poor, due to uneven terrain and

C.-L. Chang $(\varangle) \cdot$ Y.-T. Lin

Department of Water Resources Engineering and Conservation,

Feng Chia University, No. 100 Wenhwa Rd.,Seatwen,

Taichung 40724, Taiwan

e-mail: f89541201@ntu.edu.tw inconsistent distribution of rainfall. Environmental vulnerability and disaster risk are high in Taiwan. Floods and droughts negatively impact the environment and people's live (Lu et al. 2001; Chang et al. 2008a, b; Chang and Chao 2012). Besides Taiwan, many countries in the world also face troublesome water and environmental problems. Climate change has increased the difficulty of solving these problems. Sustainable water-resource management has become a critical challenge in the previous decade (Stout 1998; Loucks 2000).

Water quality management is a major issue in waterresource management (Dai and Labadie 2001). Due to increased human activities in natural watersheds, water quality is more difficult to maintain. Water pollution damages the environment and greatly impacts the watersupply system. Thus, a water quality monitoring system plays an important role in understanding actual water quality conditions. A well-planned monitoring system can provide spatial and temporal information of water quality in a river system or a watershed area. On the contrary, unsuitable design of a water quality monitoring network will result in a deficiency of water quality data and a misjudgment of water environmental conditions. Water quality management strategies should be based on correct information from a water quality monitoring system (Lo et al. 1996; Nare et al. 2006; Chilundo et al. 2008; Telci et al. 2009).

Water quality monitoring networks have traditionally been designed on the basis of experience and intuition (Park et al. 2006). However, the selection of monitoring locations should be adjusted as a result of change in the environment. The aim of the present study was to assess the suitability and stability of the water quality monitoring network design in the Taipei Water Resource Domain (TWRD). A proper design of the water quality monitoring 
network should be based on numerous factors. For this reason, multiple criteria analysis was applied in this work.

Selected criteria in a multiple criteria analysis may provide conflicting data. The Pareto optimality was, therefore, utilized to solve this problem. The VIKOR method, a multiple criteria analysis method commonly used in scientific research, is based on the concept of optimality. This study applied the VIKOR method to assess the water quality monitoring system, because it offers greater flexibility than other methods and will provide a compromise solution to conflicting data. Based on the evaluation of the current water quality monitoring system in the TWRD, the areas that require sufficient monitoring measures can be found. The monitoring stations located in these areas need careful maintenance. If there is no monitoring station in these areas, new monitoring stations are required.

\section{Materials and methods}

Site description

The TWRD is located in northern Taiwan and covers an area of $697.57 \mathrm{~km}^{2}$. It is an important water source protection area. It comprises three subwatersheds: the BeiShih Creek Basin, $316.99 \mathrm{~km}^{2}$, the Nan-Shih Creek Basin, $335.44 \mathrm{~km}^{2}$, and the Sin-Dian Creek Basin, $45.14 \mathrm{~km}^{2}$. Table 1 shows the land-use conditions in the three subwatersheds in the TWRD. Natural forest covers more than $90 \%$ of the area in the TWRD. The density of the built-up area in the Sin-Dian Creek Basin is larger than those in the Bei-Shih Creek Basin and the Nan-Shih Creek Basin. Most of the area in the Nan-Shih Creek Basin is forest.

Figure 1 shows the current water quality monitoring network in the TWRD. There are 22 water quality

Table 1 Land-use in the Taipei Water Resource Domain

\begin{tabular}{|c|c|c|c|c|c|c|c|c|c|c|c|c|}
\hline \multirow[t]{2}{*}{ Subwatershed } & \multirow[t]{2}{*}{ Subbasin } & \multicolumn{2}{|l|}{ Forest } & \multicolumn{2}{|c|}{ Farmland } & \multicolumn{2}{|c|}{ Built-up area } & \multicolumn{2}{|c|}{$\begin{array}{l}\text { Non-irrigated } \\
\text { farmland } \\
\text { without } \\
\text { vegetative } \\
\text { cover }\end{array}$} & \multicolumn{2}{|l|}{ Water } & \multirow[t]{2}{*}{$\begin{array}{l}\text { Total area } \\
\left(\mathrm{km}^{2}\right)\end{array}$} \\
\hline & & $\begin{array}{l}\text { Area } \\
\left(\mathrm{km}^{2}\right)\end{array}$ & $\%$ & $\begin{array}{l}\text { Area } \\
\left(\mathrm{km}^{2}\right)\end{array}$ & $\%$ & $\begin{array}{l}\text { Area } \\
\left(\mathrm{km}^{2}\right)\end{array}$ & $\%$ & $\begin{array}{l}\text { Area } \\
\left(\mathrm{km}^{2}\right)\end{array}$ & $\%$ & $\begin{array}{l}\text { Area } \\
\left(\mathrm{km}^{2}\right)\end{array}$ & $\%$ & \\
\hline \multirow{14}{*}{$\begin{array}{l}\text { The Bei-Shih Creek } \\
\text { Basin }\end{array}$} & 1 & 38.49 & 89.99 & 2.46 & 5.75 & 0.53 & 1.24 & 0.75 & 1.75 & 0.54 & 1.26 & 42.77 \\
\hline & 2 & 8.07 & 67.25 & 2.42 & 20.17 & 0.64 & 5.33 & 0.65 & 5.42 & 0.22 & 1.83 & 12.00 \\
\hline & 3 & 36.07 & 97.96 & 0.13 & 0.35 & 0.20 & 0.54 & 0.24 & 0.65 & 0.18 & 0.49 & 36.82 \\
\hline & 4 & 39.89 & 91.95 & 2.24 & 5.16 & 0.43 & 0.99 & 0.29 & 0.67 & 0.53 & 1.22 & 43.38 \\
\hline & 5 & 0.82 & 71.93 & 0.24 & 21.05 & 0.03 & 2.63 & 0.01 & 0.88 & 0.04 & 3.51 & 1.14 \\
\hline & 6 & 22.69 & 90.51 & 1.71 & 6.82 & 0.24 & 0.96 & 0.25 & 1.00 & 0.18 & 0.72 & 25.07 \\
\hline & 7 & 1.83 & 84.72 & 0.20 & 9.26 & 0.06 & 2.78 & 0.04 & 1.85 & 0.03 & 1.39 & 2.16 \\
\hline & 8 & 0.75 & 72.82 & 0.08 & 7.77 & 0.00 & 0.00 & 0.05 & 4.85 & 0.15 & 14.56 & 1.03 \\
\hline & 9 & 10.50 & 89.44 & 0.63 & 5.37 & 0.08 & 0.68 & 0.48 & 4.09 & 0.05 & 0.43 & 11.74 \\
\hline & 10 & 20.42 & 97.70 & 0.06 & 0.29 & 0.04 & 0.19 & 0.12 & 0.57 & 0.26 & 1.24 & 20.90 \\
\hline & 11 & 20.97 & 79.40 & 3.99 & 15.11 & 0.60 & 2.27 & 0.52 & 1.97 & 0.33 & 1.25 & 26.41 \\
\hline & 12 & 2.15 & 70.72 & 0.38 & 12.50 & 0.14 & 4.61 & 0.16 & 5.26 & 0.21 & 6.91 & 3.04 \\
\hline & 13 & 74.49 & 82.28 & 4.30 & 4.75 & 1.39 & 1.54 & 0.68 & 0.75 & 9.67 & 10.68 & 90.53 \\
\hline & Total & 277.14 & 87.43 & 18.84 & 5.94 & 4.38 & 1.38 & 4.24 & 1.34 & 12.39 & 3.91 & 316.99 \\
\hline \multirow{7}{*}{$\begin{array}{l}\text { The Nan-Shih Creek } \\
\text { Basin }\end{array}$} & 14 & 162.17 & 98.93 & 0.09 & 0.05 & 0.23 & 0.14 & 0.50 & 0.31 & 0.93 & 0.57 & 163.92 \\
\hline & 15 & 63.79 & 95.69 & 0.95 & 1.43 & 0.92 & 1.38 & 0.40 & 0.60 & 0.60 & 0.90 & 66.66 \\
\hline & 16 & 82.57 & 98.86 & 0.12 & 0.14 & 0.19 & 0.23 & 0.04 & 0.05 & 0.60 & 0.72 & 83.52 \\
\hline & 17 & 0.36 & 85.71 & 0.01 & 2.38 & 0.03 & 7.14 & 0.00 & 0.00 & 0.02 & 4.76 & 0.42 \\
\hline & 18 & 2.42 & 89.96 & 0.09 & 3.35 & 0.08 & 2.97 & 0.01 & 0.37 & 0.09 & 3.35 & 2.69 \\
\hline & 19 & 17.34 & 95.12 & 0.18 & 0.99 & 0.30 & 1.65 & 0.07 & 0.38 & 0.34 & 1.87 & 18.23 \\
\hline & Total & 328.65 & 97.98 & 1.44 & 0.43 & 1.75 & 0.52 & 1.02 & 0.30 & 2.58 & 0.77 & 335.44 \\
\hline \multirow{4}{*}{$\begin{array}{l}\text { The Sin-Dian Creek } \\
\text { Basin }\end{array}$} & 20 & 15.48 & 77.48 & 3.92 & 19.62 & 0.27 & 1.35 & 0.08 & 0.40 & 0.23 & 1.15 & 19.98 \\
\hline & 21 & 9.72 & 69.53 & 1.25 & 8.94 & 2.44 & 17.45 & 0.02 & 0.14 & 0.55 & 3.93 & 13.98 \\
\hline & 22 & 8.46 & 75.67 & 0.60 & 5.37 & 1.42 & 12.70 & 0.02 & 0.18 & 0.68 & 6.08 & 11.18 \\
\hline & Total & 33.66 & 74.57 & 5.77 & 12.78 & 4.13 & 9.15 & 0.12 & 0.27 & 1.46 & 3.23 & 45.14 \\
\hline
\end{tabular}




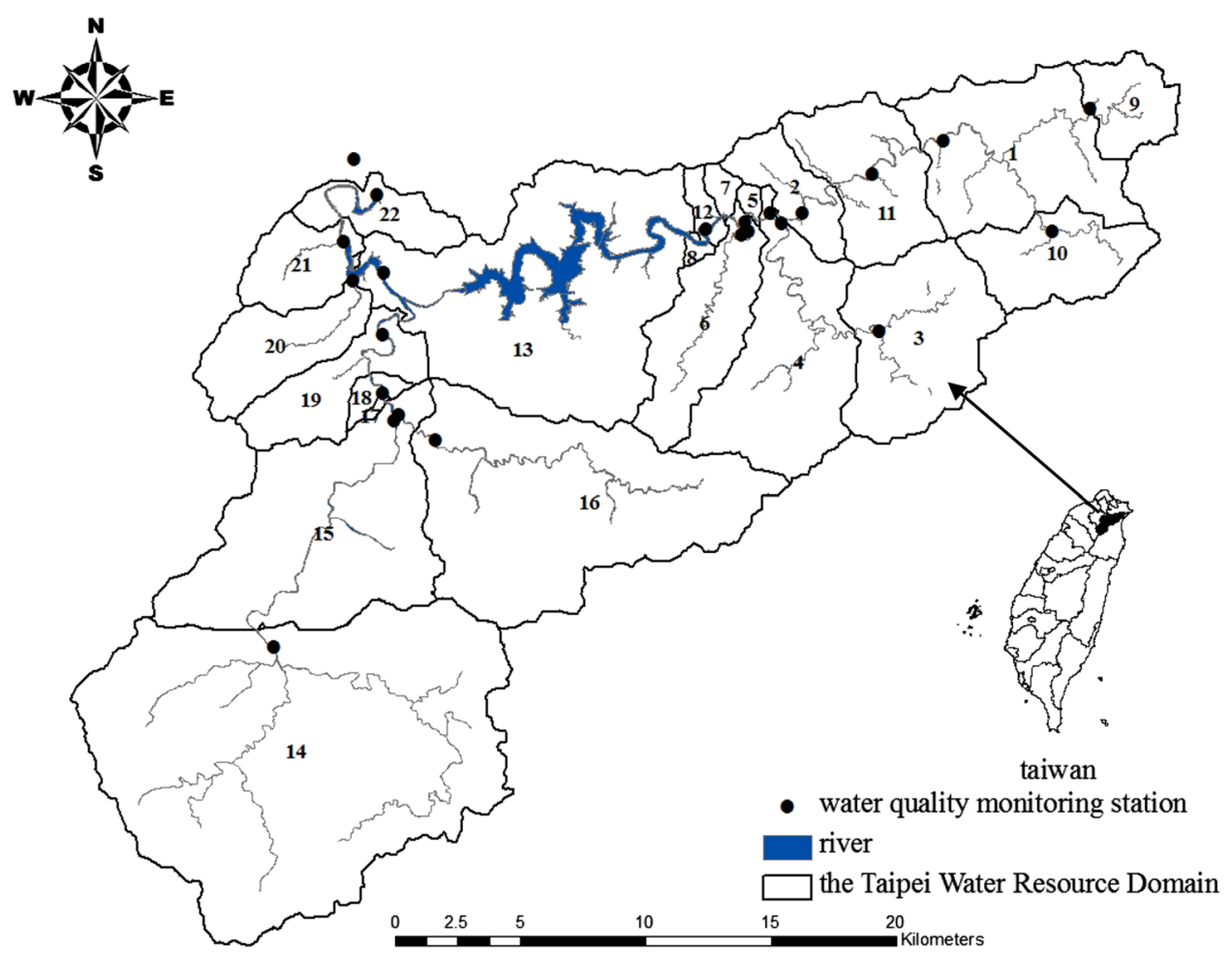

Fig. 1 Current water quality monitoring network in the Taipei Water Resource Domain. a Utility measures of the 22 subbasins. b Regret measures of the 22 subbasins. c The VIKOR indices of the 22 subbasins

monitoring stations, 13 in the Bei-Shih Creek Basin, 6 in the Nan-Shih Creek Basin, and 3 in the Sin-Dian Creek Basin. The Fei-Tsui reservoir, which is known as one of the best water quality reservoirs in Taiwan, is located in the Bei-Shih Creek Basin. On the basis of $20 \times 20 \mathrm{~m}^{2}$ digital elevation model (DEM) and the current water quality monitoring network, this study divided the TWRD into 22 subbasins. Except for Subbasins 5, 7, 8, and 17, there is at least one water quality monitoring station in each subbasin.

\section{Criteria selection}

Non-point source pollution is a major contributor to the degradation of water quality. Non-point source pollution is more difficult to control and predict than the point source pollution (Pegram and Bath 1995). The land-use condition in a river system is a major factor for watershed responses (Prakash et al. 1991; Robert et al. 2007; Chang et al. 2008a, b). Green cover ratio, landslide areas, and over-utilization of hillsides represent the pollution potential and vulnerability of areas with different land-use conditions. The areas with higher pollution potential will impact water quality; for this reason, they need stricter monitoring systems. According to the literature analysis, this study selected five criteria for multiple criteria analysis. The five criteria were non-point source pollution $\left(C_{1}\right)$, green cover ratio $\left(C_{2}\right)$, landslide area ratio $\left(C_{3}\right)$, over-utilization area ratio of hillsides $\left(C_{4}\right)$, and density of water quality monitoring stations $\left(C_{5}\right) . C_{1}$ was predicted by a watershed modelBASINS. $C_{2}, C_{3}, C_{4}$, and $C_{5}$ were calculated by geographic information system (GIS) on the basis of geographic data.

As these criteria have different units and dimensions, they need to be normalized to dimensionless criteria on a single scale (Hebert and Keenleyside 1995). The values of normalized criteria were fixed between 0 and 1 . The normalized criteria were symbolized as $C_{\mathrm{n} 1}, C_{\mathrm{n} 2}, C_{\mathrm{n} 3}, C_{\mathrm{n} 4}$, and $C_{\mathrm{n} 5}$. The value of normalized criteria indicates the necessity of a water quality monitoring station. The larger the value of $C_{1}, C_{3}$, and $C_{4}$, the higher the necessity for a water quality monitoring station. On the contrary, the lower the value of $C_{2}$ and $C_{5}$, the higher the necessity for a water quality monitoring station. Therefore, the calculations of normalization are different for these criteria. $C_{\mathrm{n} 1}, C_{\mathrm{n} 3}$, and $C_{\mathrm{n} 4}$ can be calculated by Eq. (1). $C_{\mathrm{n} 2}$ and $C_{\mathrm{n} 5}$ can be calculated by Eq. (2):

$$
\begin{gathered}
C_{\mathrm{n} i}=\frac{c_{i}-c_{i \min }}{c_{i \max }-c_{i \min }} \quad(i=1,3, \text { and } 4) \\
C_{\mathrm{n} i}=\frac{c_{i}-c_{i \max }}{c_{i \min }-c_{i \max }} \quad(i=2 \text { and } 5) .
\end{gathered}
$$

Multiple criteria analysis: the VIKOR method

Multiple criteria analysis has been popularly applied for searching the optimal solution among several alternatives on the basis of multiple factors (Bryan and Crossman 2008; 
Chung and Lee 2009; Chang and Hsu 2009). As criteria or attributes of alternatives would be in conflict, it is better to determine a compromise solution instead of an optimal solution. This study applied a compromise method, VIKOR, for searching a compromise solution. The VIKOR method considers both the utility measures and the regret measures for the alternatives. The compromise ranking is identified by comparing the measure of closeness to the optimal alternative (Tzeng et al. 2002, 2005; Opricovic and Tzeng 2004, 2007; Tong et al. 2007; Chang 2010; Chang and Hsu 2011). The algorithm of the VIKOR method is as follows:

1. Determine the alternatives and criteria. The subbasins can be regarded as alternatives, which are denoted as $X_{1}, X_{2}, \ldots, X_{j}, \ldots$, and $X_{22}$. The criteria are $C_{\mathrm{n} 1}, C_{\mathrm{n} 2}, \ldots$, $C_{\mathrm{n} i}, \ldots$, and $C_{\mathrm{n} 5}$.

2. Calculate the values of $f_{i j}, f_{i}^{*}$, and $f_{i}^{-} . f_{i j}$ is the value of the $i$ th criterion for Subbasin $j . f_{i}^{*}$ and $f_{i}^{-}$are the maximum and the minimum value of each criterion $i$. As the normalized criteria have been fixed between 0 and 1 , the values of $f_{i}^{*}$, and $f_{i}^{-}$are 1 and 0 , respectively.

3. Calculate the values of $S_{j}$ and $R_{j}$ by Eqs. (3) and (4). $S_{j}$ and $R_{j}$ represents the utility measure and the regret measure for Subbasin $j$, respectively. This study assumed the weights of criteria were all the same. Thus, $w_{i}(i=1,2, \ldots$, and 5$)$ were given by 0.2 .

$$
\begin{aligned}
& S_{j}=\sum_{i=1}^{n} w_{i}\left(f_{i}^{*}-f_{i j}\right) /\left(f_{i}^{*}-f_{i}^{-}\right) \\
& R_{j}=\max \left[w_{i}\left(f_{i}^{*}-f_{i j}\right) /\left(f_{i}^{*}-f_{i}^{-}\right)\right]
\end{aligned}
$$

4. Calculate the value of $Q_{j} . Q_{j}$ is the VIKOR index for Subbasin $j$. The lower the value of $Q$, the better the alternative. Thus, the subbasins with lower $Q$ should have a complete water quality monitoring system. In Eq. (5), $S^{*}$ and $S^{-}$are the minimum and the maximum utility measure for the subbasins. $R^{*}$ and $R^{-}$are the minimum and the maximum regret measure for the subbasins.

$$
Q_{j}=\left(S_{j}-S^{*}\right) /\left(S^{-}-S^{*}\right)+\left(R_{j}-R^{*}\right) /\left(R^{-}-R^{*}\right)
$$

\section{Results and discussion}

Environmental characteristics of the subbasins

The environmental properties of the 22 subbasins in the

\begin{tabular}{|c|c|c|c|c|c|c|c|c|c|}
\hline \multirow{2}{*}{ Subwatershed } & \multirow{2}{*}{ Subbasin } & \multicolumn{4}{|c|}{ Non-point source pollution } & \multirow{2}{*}{$\begin{array}{l}\text { Green } \\
\text { cover } \\
\text { ratio } \\
(\%)\end{array}$} & \multirow{2}{*}{$\begin{array}{l}\text { Landslide } \\
\text { area ratio } \\
(\%)\end{array}$} & \multirow{2}{*}{$\begin{array}{l}\text { Over- } \\
\text { utilization } \\
\text { area ratio of } \\
\text { hillsides }(\%)\end{array}$} & \multirow{2}{*}{$\begin{array}{l}\text { Density of water } \\
\text { quality monitoring } \\
\text { stations } \\
(\text { station } / \mathrm{km})\end{array}$} \\
\hline & & $\begin{array}{l}\text { SS } \\
\text { (kg/year/ha) }\end{array}$ & $\begin{array}{l}\mathrm{TP} \\
\text { (kg/year/ha) }\end{array}$ & $\begin{array}{l}\text { BOD } \\
\text { (kg/year/ha) }\end{array}$ & $\begin{array}{l}\mathrm{NH} 3-\mathrm{N} \\
\text { (kg/year/ha) }\end{array}$ & & & & \\
\hline \multirow{13}{*}{$\begin{array}{l}\text { The Bei-Shih } \\
\text { Creek } \\
\text { Basin }\end{array}$} & 1 & 492.26 & 0.29 & 0.99 & 0.0004 & 89 & 0.02 & 3.00 & 0.02 \\
\hline & 2 & $6,133.60$ & 2.42 & 0.48 & 0.0036 & 67 & 0.73 & 10.00 & 0.06 \\
\hline & 3 & 860.13 & 0.62 & 0.76 & 0.0023 & 97 & 0.06 & 0.40 & 0.04 \\
\hline & 4 & $2,531.42$ & 0.79 & 1.54 & 0.0017 & 92 & 0.05 & 1.50 & 0.05 \\
\hline & 5 & 736.24 & 1.37 & 15.15 & 0.0033 & 73 & 0.00 & 18.50 & 0.00 \\
\hline & 6 & $2,843.01$ & 0.80 & 0.02 & 0.0001 & 90 & 0.10 & 0.90 & 0.10 \\
\hline & 7 & 486.43 & 0.88 & 8.23 & 0.0018 & 85 & 0.28 & 12.20 & 0.00 \\
\hline & 8 & $4,708.55$ & 2.15 & 4.11 & 0.0038 & 73 & 0.00 & 0.00 & 0.00 \\
\hline & 9 & $5,132.92$ & 0.86 & 9.21 & 0.0020 & 87 & 0.01 & 8.00 & 0.07 \\
\hline & 10 & $5,968.65$ & 0.73 & 0.22 & 0.0018 & 96 & 0.00 & 0.00 & 0.05 \\
\hline & 11 & $2,827.18$ & 2.39 & 0.25 & 0.0029 & 79 & 0.00 & 6.10 & 0.03 \\
\hline & 12 & 25.97 & 0.48 & 0.76 & 0.0007 & 70 & 0.00 & 2.00 & 0.20 \\
\hline & 13 & 58.83 & 0.40 & 0.02 & 0.0008 & 82 & 0.11 & 3.50 & 0.01 \\
\hline \multirow{6}{*}{$\begin{array}{l}\text { The Nan- } \\
\text { Shih Creek } \\
\text { Basin }\end{array}$} & 14 & 460.73 & 0.70 & 0.01 & 0.0017 & 99 & 0.01 & 0.50 & 0.01 \\
\hline & 15 & $2,613.12$ & 0.78 & 0.03 & 0.0017 & 96 & 0.06 & 2.10 & 0.03 \\
\hline & 16 & $2,598.53$ & 0.64 & 0.02 & 0.0017 & 98 & 0.00 & 0.50 & 0.01 \\
\hline & 17 & $3,289.20$ & 0.17 & 4.54 & 0.0009 & 86 & 0.00 & 4.30 & 0.00 \\
\hline & 18 & 954.65 & 0.15 & 2.47 & 0.0008 & 90 & 0.00 & 4.00 & 0.20 \\
\hline & 19 & $4,454.22$ & 0.72 & 0.14 & 0.0016 & 95 & 0.02 & 0.80 & 0.04 \\
\hline \multirow{3}{*}{$\begin{array}{l}\text { The Sin-Dian } \\
\text { Creek } \\
\text { Basin }\end{array}$} & 20 & $3,491.37$ & 1.57 & 1.08 & 0.0024 & 77 & 0.02 & 15.40 & 0.06 \\
\hline & 21 & $4,548.85$ & 0.86 & 3.49 & 0.0016 & 60 & 0.00 & 9.20 & 0.04 \\
\hline & 22 & $3,273.05$ & 0.35 & 2.72 & 0.0010 & 70 & 0.01 & 2.90 & 0.04 \\
\hline
\end{tabular}
TWRD are shown in Table 2. This study considered four

Table 2 Environmental information of the 22 subbasins in TWRD 
pollutants: SS, TP, BOD, and $\mathrm{NH}_{3}-\mathrm{N}$. Among the 22 subbasins, Subbasin 2 has the largest amounts of SS and TP, $6,133.60$ and $2.42 \mathrm{~kg} / \mathrm{year} / \mathrm{ha}$; Subbasin 5 has the largest amount of BOD, $15.15 \mathrm{~kg} / \mathrm{year} / \mathrm{ha}$; Subbasin 8 has the largest amount of $\mathrm{NH}_{3}-\mathrm{N}, 0.0038 \mathrm{~kg} / \mathrm{year} / \mathrm{ha}$. On the basis of the simulation result following the BASINS model, it is demonstrated that Subbasins 2, 8, 5, 9, and 11 are the top five subbasins with high pollution exports in the TWRD. All these subbasins are located in the Bei-Shih Creek Basin.

According to the analysis of land-use condition, Subbasin 21 has the least green cover ratio at only $60 \%$. The top five subbasins with the least green cover ratio are, in order, Subbasins 21, 2, 12, 22, and 5. The green cover ratios of the subbasins in the Nan-Shih Creek Basin are all larger than $85 \%$. The green cover ratios of the subbasins in the Sin-Dian Creek Basin are all $<80 \%$. The area and the area percentage of the subbasins with $<80 \%$ green cover ratio in the Bei-Shih Creek Basin are about $43.62 \mathrm{~km}^{2}$ and $13.76 \%$, respectively.

Subbasin 2 has the largest landslide area ratio at $0.73 \%$. Except for Subbasin 2, the landslide area ratios of the other 21 subbasins are less than $0.3 \%$. It indicates that the landslide area ratio of Subbasin 2 is much higher than those of the other 21 subbasins. Subbasin 5 has the largest over-

Table 3 Normalized values of criteria of the 22 subbasins in TWRD

\begin{tabular}{lcccccc}
\hline Subwatershed & Subbasin & $C_{\mathrm{n} 1}$ & $C_{\mathrm{n} 2}$ & $C_{\mathrm{n} 3}$ & $C_{\mathrm{n} 4}$ & $C_{\mathrm{n} 5}$ \\
\hline The Bei-Shih Creek & 1 & 0.00 & 0.26 & 0.03 & 0.16 & 0.90 \\
Basin & 2 & 1.00 & 0.82 & 1.00 & 0.54 & 0.70 \\
& 3 & 0.26 & 0.05 & 0.08 & 0.02 & 0.80 \\
& 4 & 0.35 & 0.18 & 0.07 & 0.08 & 0.75 \\
& 5 & 0.82 & 0.67 & 0.00 & 1.00 & 1.00 \\
& 6 & 0.17 & 0.23 & 0.14 & 0.05 & 0.50 \\
& 7 & 0.41 & 0.36 & 0.38 & 0.66 & 1.00 \\
& 8 & 0.97 & 0.67 & 0.00 & 0.00 & 1.00 \\
& 9 & 0.73 & 0.31 & 0.01 & 0.43 & 0.65 \\
The Nan-Shih Creek & 14 & 0.52 & 0.08 & 0.00 & 0.00 & 0.75 \\
Basin & 14 & 0.17 & 0.00 & 0.01 & 0.03 & 0.95 \\
& 11 & 0.71 & 0.51 & 0.00 & 0.33 & 0.85 \\
Basin & 12 & 0.02 & 0.74 & 0.00 & 0.11 & 0.00 \\
& 13 & 0.31 & 0.08 & 0.08 & 0.11 & 0.85 \\
& 16 & 0.29 & 0.03 & 0.00 & 0.03 & 0.95 \\
& 17 & 0.28 & 0.33 & 0.00 & 0.23 & 1.00 \\
& 18 & 0.08 & 0.23 & 0.00 & 0.22 & 0.00 \\
& 19 & 0.41 & 0.10 & 0.03 & 0.04 & 0.80 \\
& 20 & 0.60 & 0.56 & 0.03 & 0.83 & 0.70 \\
& 21 & 0.52 & 1.00 & 0.00 & 0.50 & 0.80 \\
& 22 & 0.28 & 0.74 & 0.01 & 0.16 & 0.80 \\
\hline
\end{tabular}

utilization area ratio of hillsides at $18.5 \%$. The top five subbasins with a high over-utilization area ratio of hillsides are, in order, Subbasins 5, 20, 7, 2, and 21. The result shows that the land-use condition in the Nan-Shih Creek Basin has less negative impact on the water quality than those in the Bei-Shih Creek Basin and the Sin-Dian Creek Basin.

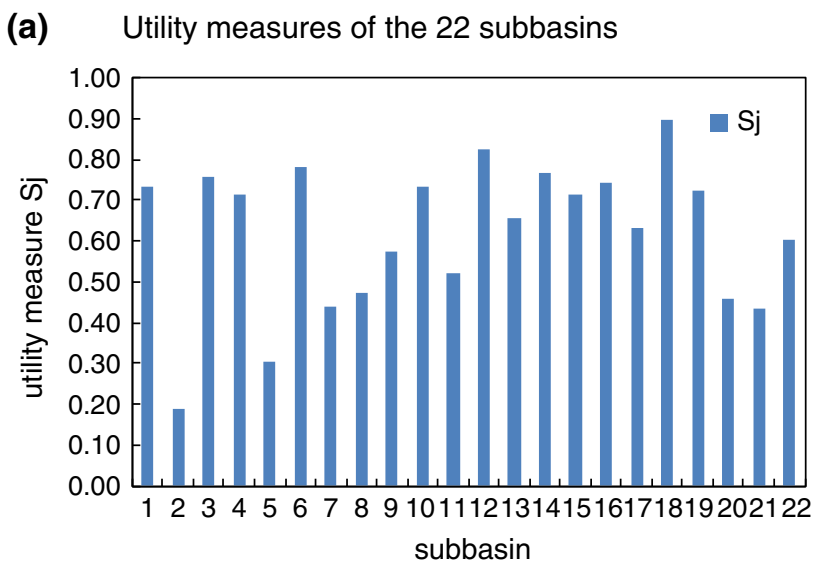

(b) Regret measures of the 22 subbasins
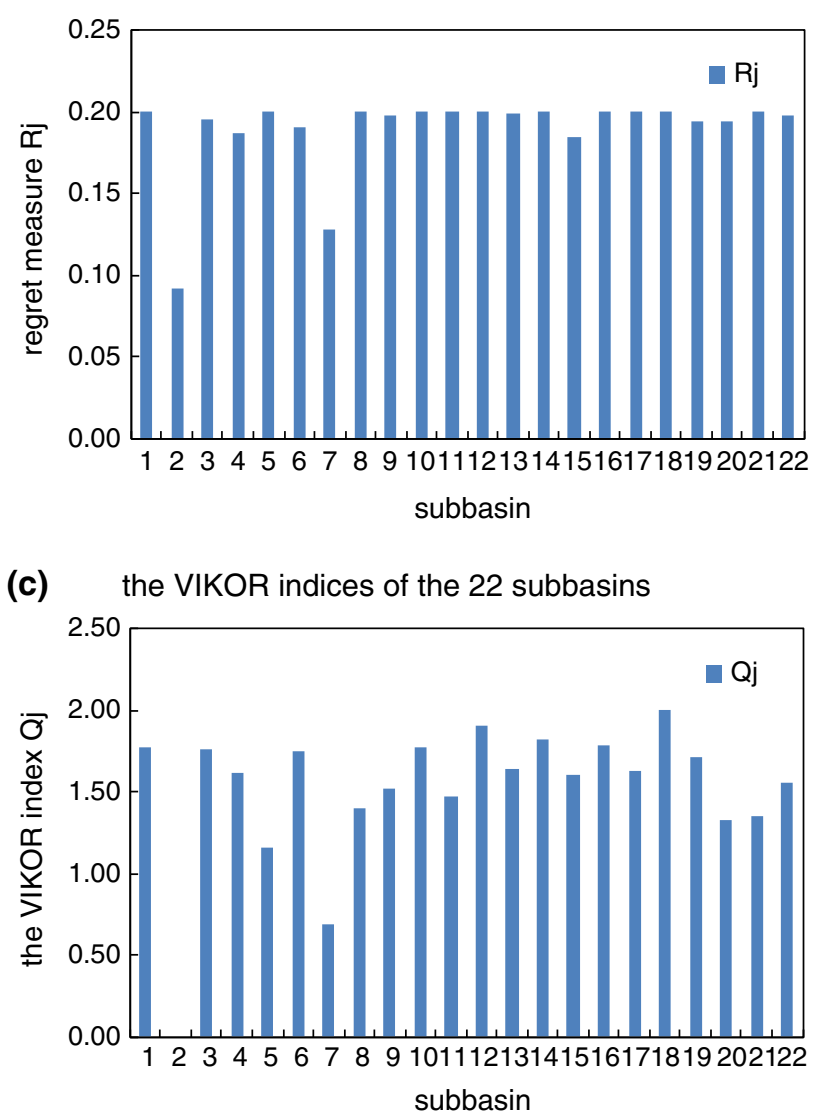

Fig. 2 Utility measures, regret measures, and the VIKOR indices of the 22 subbasins in TWRD 
Fig. 3 Subbasins with a higher necessity for a water quality monitoring system

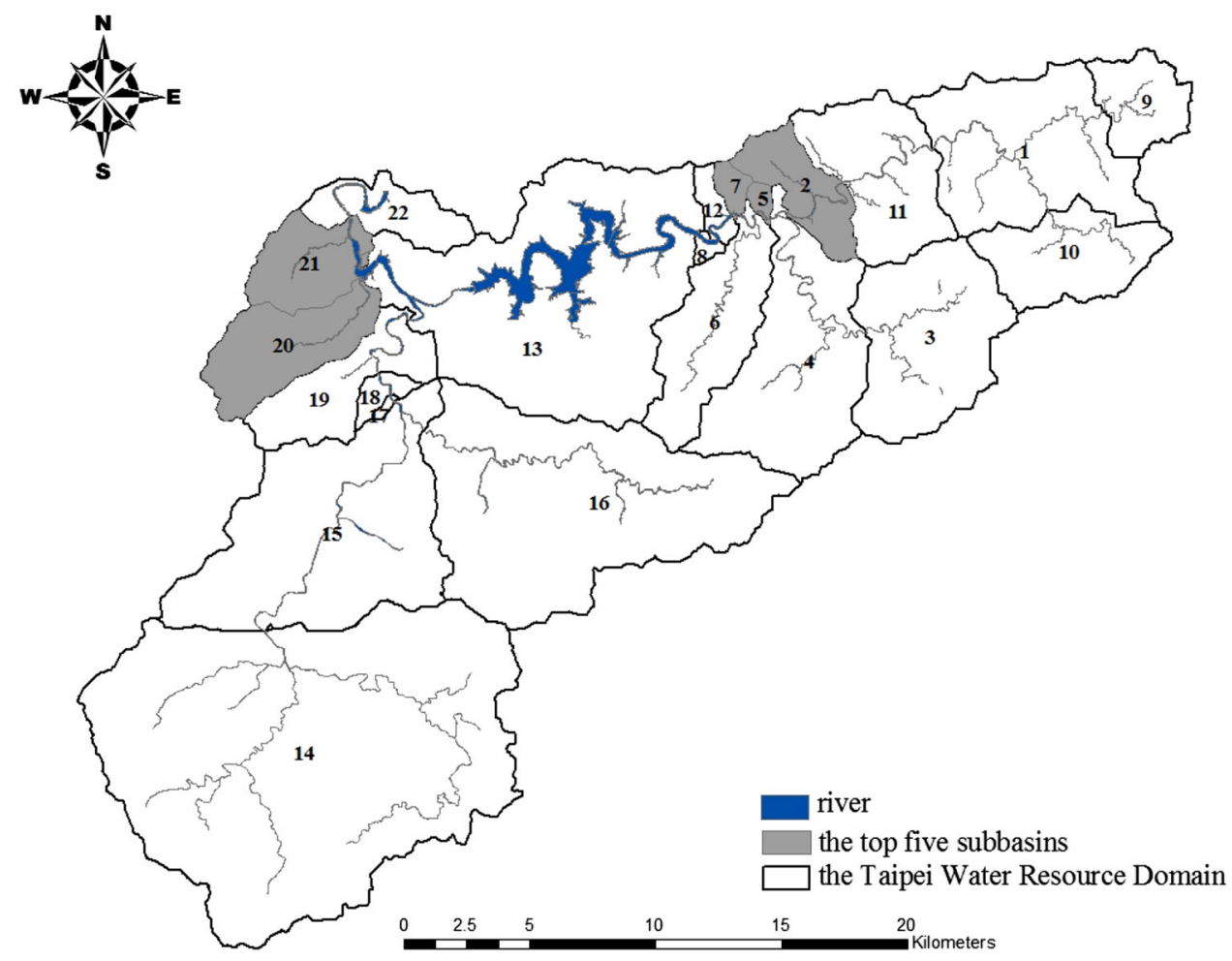

Evaluation of the water quality monitoring network

The five criteria were normalized and fixed between 0 and 1 . Table 3 shows the normalized criteria $C_{\mathrm{n} 1}, C_{\mathrm{n} 2}, C_{\mathrm{n} 3}, C_{\mathrm{n} 4}$, and $C_{\mathrm{n} 5}$ of the 22 subbasins in the TWRD. The subbasins with larger values of normalized criteria have a higher need for a water quality monitoring system. Besides the environmental properties of each subbasin discussed above, the current water quality monitoring network is also a critical factor for evaluating the monitoring system. Subbasins 5, 7, 8, and 17 do not have water quality monitoring station. There are two water quality stations in Subbasins 4 and 15, and three water quality stations in Subbasin 6. The other subbasins have one water quality monitoring station. The densities of water quality stations are zero in Subbasins 5, 7, 8, and 17; thus, the criteria values of $C_{\mathrm{n} 5}$ for these subbasins are 1 .

The necessity of a water quality monitoring system has to be based on the five criteria. Figure 2 shows the analysis results by the VIKOR method. The larger the value of $S_{j}$, the lesser the group utility. When this study only considered the utility measure, the top five subbasins with a higher necessity for a water quality monitoring system are, in order, Subbasins 2, 5, 21, 7, and 20. The larger the value of $R_{j}$, the larger the individual regret. When this study only considered the regret measure, the top five subbasins with a higher necessity for a water quality monitoring system are, in order, Subbasins 2, 7, 15, 4, and 6. The variability of the regret measures for the subbasins is not noticeable. The standard deviations of $S_{j}$ and $R_{j}$ are 0.18 and 0.03 , respectively. The result indicates that the judgment ability of the utility measure is better than that of the regret measure in this study.

To integrate the influences of the utility measures and the regret measures in the multiple criteria analysis, the VIKOR index $Q_{j}$ is useful. The standard deviation of $Q_{j}$ is 0.44 , which is larger than the standard deviations of $S_{j}$ and $R_{j}$. According to the VIKOR index $Q_{j}$, the top five subbasins with a higher necessity for a water quality monitoring system are, in order, Subbasins 2, 7, 5, 20, and 21. The result shows that Subbasin 2 has the highest group utility and the least individual regret among the 22 subbasins in the TWRD; thus, the necessity for a water quality monitoring system is the highest in Subbasin 2. The ranking of $Q_{j}$ can be a useful decision basis for the design of the water quality monitoring system in the TWRD. The lower the value of $Q_{j}$, the higher the need for a water quality monitoring system.

This study recommended several areas for setting up new monitoring stations. Figure 3 shows the top five subbasins with a higher necessity for a water quality monitoring system according to the VIKOR index. The current water quality monitoring stations in Subbasins 2, 20, and 
21 need careful maintenance. As there is no water quality monitoring station in Subbasins 5 and 7, new monitoring stations are required. If the national financial budget is sufficient, increased stations should be immediately set up in these subbasins.

The result shows that the necessity for water quality monitoring stations is high in the Bei-Shih Creek Basin and the Sin-Dian Creek Basin. Although there are already 13 water quality monitoring stations in the BeiShih Creek Basin, increased monitoring stations are required. On the contrary, the Nan-Shih Creek Basin can accept fewer water quality monitoring stations as a result of better environmental properties. The current water quality monitoring stations are sufficient in the Nan-Shih Creek Basin. Although Subbasins 8 and 17 are without water quality monitoring stations, this is still considered to be acceptable.

\section{Conclusion}

The design of a water quality monitoring network has to be based on numerous factors. Thus, this study applied multiple criteria analysis to assess the suitability of the current water quality monitoring system in the TWRD. Several areas that have a high need for sufficient water quality monitoring records were also recommended.

The VIKOR method considers both the utility measure and the regret measure of each subbasin. It is an impersonal multiple criteria decision-making method for assessing the current water quality monitoring network in the TWRD. As the environmental properties in Subbasin 2 may have a high negative impact on water quality, it has the highest need for sufficient monitoring records for controlling water quality conditions. The current water quality monitoring station in Subbasin 2 needs careful maintenance. If government financial considerations are sufficient, increased monitoring stations are required.

On the basis of the VIKOR index $Q_{j}$, the ranking of the necessity for a water quality monitoring system is clear. The subbasins with lower $Q_{j}$ have higher need for monitoring records of water quality. The result indicates that the Bei-Shih Creek Basin and the Sin-Dian Creek Basin have a higher need for water quality stations than the Nan-Shih Creek Basin. Although the Nan-Shih Creek Basin covers a large area, it can accept fewer water quality monitoring stations than the Bei-Shih Creek Basin and the Sin-Dian Creek Basin. When government finances are limited, station maintenance becomes an important task in water quality management. When there are sufficient finances, building new water quality monitoring stations is a more effective method in water quality management. The results from this study can be an important reference.
Acknowledgments The authors would like to thank the National Science Council of the Republic of China for financially supporting this research under Contract No. NSC 100-2221-E-035-072-MY3.

\section{References}

Bryan BA, Crossman ND (2008) Systematic regional planning for multiple objective natural resource management. J Environ Manage 88:1175-1189

Chang CL (2010) A modified VIKOR method for multiple criteria analysis. Environ Monit Assess 168(1-4):339-344

Chang CL, Chao YC (2012) Using the analytical hierarchy process to assess the environmental vulnerabilities of basins in Taiwan. Environ Monit Assess 184(5):2939-2945

Chang CL, Hsu CH (2009) Multi-criteria analysis via the VIKOR method for prioritizing land-use restraint strategies in the TsengWen reservoir watershed. J Environ Manage 90(11):3226-3230

Chang CL, Hsu CH (2011) Applying a modified VIKOR method to classify land subdivisions according to watershed vulnerability. Water Resour Manage 25(1):301-309

Chang CL, Chiueh PT, Peng YS (2008a) A vulnerability analysis in the Fei-tsui reservoir watershed in Taiwan. Environ Monit Assess 143(1-3):9-14

Chang CL, Kuan WH, Lui PS, Hu CY (2008b) Relationship between landscape characteristics and surface water quality. Environ Monit Assess 147(1-3):57-64

Chilundo M, Kelderman P, Okeeffe JH (2008) Design of a water quality monitoring network for the Limpopo River Basin. Phys Chem Earth 33:655-665

Chung ES, Lee KS (2009) Prioritization of water management for sustainability using hydrologic simulation model and multicriteria decision making techniques. J Environ Manage 90:15021511

Dai BT, Labadie JW (2001) River basin network model for integrated water quantity/quality management. J Water Resour Plan Manag 127(5):295-305

Hebert CE, Keenleyside AA (1995) To normalize or not to normalize? Fat is the question. Environ Toxicol Chem 14(5):801-807

Lo SL, Kuo JT, Wang SM (1996) Water quality monitoring network design of Keelung river, northern Taiwan. Water Sci Technol 34(12):49-57

Loucks DP (2000) Sustainable water resources management. Water Int 25(1):3-10

Lu SY, Cheng JD, Brooks KN (2001) Managing forests for watershed protection in Taiwan. For Ecol Manage 143:77-85

Nare L, Love D, Hoko Z (2006) Involvement of stakeholders in the water quality monitoring and surveillance system: the case of Mzingwane Catchment, Zimbabwe. Phys Chem Earth 31:707712

Opricovic S, Tzeng GH (2004) Compromise solution by MCDM methods: a comparative analysis of VIKOR and TOPSIS. Eur J Oper Res 156:445-455

Opricovic S, Tzeng GH (2007) Extended VIKOR method in comparison with outranking methods. Eur J Oper Res 178:514-529

Park SY, Choi JH, Wang S, Park SS (2006) Design of a water quality monitoring network in a large river system using the genetic algorithm. Ecol model 199:289-297

Pegram GC, Bath AJ (1995) Role of non-point sources in the development of a water quality management plan for the Mgeni River Catchment. Water Sci Technol 32:5-6

Prakash B, Lawrence DT, Kathryn MF, Lockbay BG (1991) Relationships between landscape characteristics and nonpoint source pollution inputs to coastal estuaries. Environ Manage 23(4):539-549 
Robert AZ, Nicholas AP, Richard GL, Charles LD (2007) Relationship of land-use/land-cover patterns and surface-water quality in the Mullica River basin. J Am Water Resour Assoc 43(3):594604

Stout GE (1998) Sustainable development requires the full cooperation of water users. Water Int 23(1):3-7

Telci IT, Nam K, Guan J, Aral MM (2009) Optimal water quality monitoring network design for river systems. J Environ Manage 90:2987-2998
Tong LI, Chen CC, Wang CH (2007) Optimization of multi-response processes using the VIKOR method. Int J Adv Manuf Technol 31:1049-1057

Tzeng GH, Teng MH, Chen JJ, Opricovic S (2002) Multicriteria selection for a restaurant location in Taipei. Int $\mathbf{J}$ Hosp Manag 21(2):171-187

Tzeng GH, Lin CW, Opricovic S (2005) Multi-criteria analysis of alternative-fuel buses for public transportation. Energy Policy 33:1373-1383 